\title{
Cointegration and the Demand for
}

\section{Energy in Fiji}

\author{
Saten Kumar \\ School of Economics, Auckland University of Technology, New Zealand
}

\begin{abstract}
This paper applies alternative time series techniques such as General to Specific (GETS) and Johansen Maximum Likelihood (JML) to estimate the long run income and price elasticities of demand for energy for Fiji. We also test for the causal relationship between energy consumption, GDP and energy prices using the Granger causality tests. Our results imply that there is a uni-directional causality running from GDP to energy consumption.
\end{abstract}

Keywords: Energy consumption, GDP, income elasticity and energy price elasticity.

JEL Numbers: C22; Q41

Acknowledgements: The author is grateful to Prof. B. Bhaskara Rao for comments on an earlier version of the paper. The Editor and the two anonymous referees are also acknowledged for providing useful suggestions.

Contact author: Saten Kumar, AUT University, School of Economics, Private Bag 92006, Auckland 1142, New Zealand. Email: kumar_saten@yahoo.com 


\section{Introduction}

The causal relationship between energy consumption and GDP is a well-researched topic in many countries. There have been several attempts to find the direction of causality between energy consumption and GDP using alternative techniques. The direction of causality has significant policy implications especially for energy conservation. Estimating energy demand functions is important because it provides information about income and price elasticities. Having accurate information on income and price elasticities of energy demand is vital for projecting the future demand for energy and in planning the required capacity to meet future domestic consumption.

The developing countries per capita energy consumption is significantly less than that in industrialised countries. Nevertheless, the annual rate of growth in energy consumption in the developing countries is three to four times higher than in industrialised countries. Research by the International Energy Agency (IEA) forecasts that the worldwide consumption of oil by developing countries will rise by about 15 percent from 1999 to 2020 (IEA, 2001 and De Vita et.al, 2006). Therefore, there is need for massive investment in energy generation capacity to meet the increasing global demand for energy.

Numerous studies have investigated the long run relationship between energy consumption, income and energy prices. Recent studies that made significant contribution to the literature are Al-faris (1992), Eltony and Hoque (1996), Mohammad and Eltony (1996), Masih and Masih (1996a \& b), Cheng and Lai (1997), Brenton (1997), Diabi (1998), Ghali (1998), Pesaran et.al (1998), Sinton and Fridley (2000), Aqeel and Butt (2001), Hondroyiannis et.al (2002), Soytas and Sari (2003), Fisher-Vanden et.al (2004), Al-Iriani (2006), Wolde-Rufael (2006), Lee (2005), Yoo (2006), Mahadevan and AsafuAdjaye (2007) and Chiou-Wei et.al (2008). However, there are limited empirical studies on the demand for energy for small island states, for example, Fiji with only a few studies (Narayan and Singh, 2007 and Rao and Rao, 2009a \& b). The extensive use of energy in Fiji has useful implications on the growth and development. Fiji is heavily dependent on imported petroleum products to meet its domestic energy demands and as such high amounts of foreign earnings are diverted towards payments for these imported products. If known the determinants of energy demand, then important policies can be formulated for energy conservation and also to enhance output growth.

Note that the previous studies related to energy in Fiji have analysed only a particular energy product. While Narayan and Singh (2007) examined electricity consumption, Rao and Rao (2009a \& b) examined gasoline demand and energy efficiency, respectively. There are no empirical studies that analysed the total energy demand for Fiji and therefore our study fills this gap by estimating the long run elasticities of energy demand and testing the causality relationship between energy consumption, GDP and energy prices for Fiji over the period 1970-2005.

The remainder of the paper is organized as follows: In Section 2, we briefly discuss the trends in growth of energy consumption in Fiji. In Section 3, we provide a 
brief overview of the empirical works on energy demand in developing countries. Sections 4 and 5 detail the empirical findings and conclusions with some policy implications, respectively.

\section{Trends in Growth of Energy Consumption}

We now briefly discuss the broad trends in the average rates of growth of energy consumption, real income, real energy prices and energy output ratios to provide a backdrop and to discuss the policy implications of our findings. The main sources of energy in Fiji are electricity, unleaded gasoline, automotive diesel, industrial diesel, kerosene and gas. We refer Total energy is the sum of all these energy sources. The average growth rates of energy consumption $(\Delta \ln E)$, real GDP $(\Delta \ln Y)$, real energy price $(\Delta \ln P)$ and energy output ratios $(\Delta \ln (E / Y))$ are given in Table 1 for the entire period 1970-2005 and for the sub-periods 1970-1980, 1981-1990, 1991-2000 and 2001-2005. Note that $E / Y$ represents the energy consumption share of GDP.

\{Table 1 about here

Over the period 1970-2005, energy consumption growth has been quite volatile. The rate of growth of energy consumption and real GDP was high at about 4 and 5 percent, respectively, during 1970-80. Both energy consumption and real GDP growth have been low during the period 1981-2000. This has been due to political instabilities of 1987 and 2000 that caused poor economic growth performance for Fiji. Indeed the growth of energy output ratios was high at 0.86 percent during $1970-80$ but declined subsequently to an average of 0.45 percent during 1980s and 1990s. Generally, the growth of energy output ratios showed a slight increase from 1981 to 2005.

Further, the energy price growth has been quite significantly high ranging from 4 to 8 percent during the sample period (1970-2005). This could be due to two reasons. First, the shortages that resulted from the energy crises for example, OPEC embargo (1973-74), Iranian revolution (1979-80), Gulf war (1990-91), and Iraq war (2003). Second, the general rise in energy prices are also regarded as an important government policy measure to encourage energy saving in Fiji.

\section{Overview of Empirical Studies}

In the recent literature, we can find cointegration analyses for Jordan (Al-Azzam and Hawdon, 1999 and Saed, 2004), Turkey (Lise and Montfort, 2007), Namibia (De Vita et.al, 2006), Iran (Zamani, 2006), China (Wolde-Rufael, 2004), OECD (Al-Rabbaie and Hunt, 2004), Fiji (Narayan and Singh, 2007; Rao and Rao, 2009a \& b), Taiwan (Holtedahl and Joutz, 2004) and Malawi (Jumbe, 2004). More details about these studies are summarized in Table $2 .^{1}$

\footnotetext{
${ }^{1}$ All of these studies are about energy consumption and GDP and/or energy prices relationship, however, Al-Azzam and Hawdon (1999), De Vita et.al (2006) and Narayan and Singh (2007) have also used additional explanatory variables. The following paragraphs provide further discussion.
} 
\{Table 2 about here

Al-Azzam and Hawdon (1999) examined the elasticities of demand for energy for Jordan using annual data from 1968-1997. Using Johansen Maximum Likelihood (JML) and Stock-Watson Dynamic Ordinary Least Squares (DOLS) techniques, they found a long run cointegrating relationship between energy consumption, real income, real energy prices and construction activity. ${ }^{2}$ Both the methods provide unit income elasticity. The energy price elasticity was -0.22 and -0.08 with the JML and DOLS techniques, respectively. Saed (2004) estimated the long run elasticities of demand for energy in Jordan using the DOLS technique. The period 1980-1999 was considered. Their results suggest that the income and price elasticity of energy demand is 1.15 and -1.14 , respectively.

Lise and Montfort (2007) present the results of a study into the causality between energy consumption and GDP in Turkey with annual data from 1970-2003. They find that causality runs uni-directionally from GDP to energy consumption. De Vita et. al (2006) employed quarterly data from 1980(Q1) to 2002(Q4) to estimate demand for energy for Namibia. Using the Auto Regressive Distributed Lag (ARDL) technique, they found that there exists a cointegrating relationship between energy consumption, real GDP and air temperature. The estimated income elasticity of energy demand was around 1.3 and the elasticity with respect to energy price was around -0.3 . The energy consumption appears to be income elastic, price inelastic and sensitive to mean minimum temperature.

Zamani (2006) investigated the causal relationship between economic activities and energy consumption using JML technique for Iran for the period 1967-2003. He found a long run uni-directional relationship from GDP to total energy consumption and a bi-directional relationship between GDP and gas as well as GDP and petroleum products consumption. Wolde-Rufael (2004) examined the causal relationship between various kinds of industrial energy consumption and GDP in Shanghai for the period 1952-1999. The empirical evidence from disaggregated energy series suggest that there is a unidirectional causality running from coal, coke, electricity and total energy consumption to real GDP.

Al-Rabbaie and Hunt (2004) used panel cointegration test of Pedroni (2001) to estimate energy demand for 17 OECD countries over the period 1960-2000. Their results suggests that the country specific long run energy price and income elasticities lie in the range of -0.02 to -0.03 and 0.4 to 1.1 , respectively. The mean elasticity of income and energy price based on panel group FMOLS with time dummies are 0.96 and -0.09 , respectively.

Rao and Rao (2009a) estimated the gasoline demand function for Fiji for the period 1970-2005. Their results with alternative time series techniques reveal that the income and price elasticities of gasoline demand, respectively, are about 0.45 and -0.20 .

\footnotetext{
${ }^{2}$ Construction activity represents the total area constructed in square meters. It is an indicator of the development process involving re-settlement and urbanization.
} 
They assert that gasoline demand is both price and income inelastic. In another study, Rao and Rao (2009b) used Bai-Perron structural break tests to determine energy efficiency in Fiji using data from 1970-2005. They found that in all cases energy output ratios declined by about 26 percent by 2005 .

Narayan and Singh (2007) examined the relationship between electricity consumption, real GDP and labour force for Fiji for the period 1971-2002. ${ }^{3}$ They used ARDL technique and found that there was one cointegrating relationship among the variables when GDP was the endogenous variable. They investigated the direction of causation among the variables using Granger causality tests and found a uni-directional causality running from electricity consumption to GDP in the long run and a bidirectional causality running from GDP to labour force in the short run.

Holtedahl and Joutz (2004) utilized the JML technique to estimate electricity consumption for Taiwan for the period 1955-1996. They obtained an income elasticity of around unity and energy price elasticity of -0.16 . Jumbe (2004) also employed JML technique to investigate the causality relationship between electricity consumption and GDP for Malawi for the period 1970-1999. Their results suggest that causality runs oneway from GDP to electricity consumption. This implies that a permanent rise in GDP may cause a permanent growth in electricity consumption in Malawi.

\section{Empirical Results}

\subsection{Specification and Unit Root Tests}

Since the information on income and price elasticities of energy demand are crucial, it is vital to avoid misspecification bias. Such information can also be unreliable if proper account is not taken of the time series properties of the variables used in the investigation. We follow Hunt et.al (2003) and Al-Azzam and Hawdon (1999) and specify a simple long run demand for energy model.

$$
E_{t}=\mathrm{f}\left(Y_{t}, P_{t}\right)
$$

where $E$ is aggregate energy consumption (electricity, unleaded gasoline, automotive diesel, industrial diesel, kerosene and gas), $Y$ represents real GDP (income), $P$ is the real price of energy. The log linear specification that represents the long run energy demand model is as follows:

$$
\ln E_{t}=\beta_{0}+\beta_{1} \ln Y_{t}-\beta_{2} \ln P_{t}+\varepsilon_{t}
$$

The iid error term is denoted by $\varepsilon$. Our prior expectations are that the income elasticity for energy demand is positive and the elasticity with respect to price is negative.

\footnotetext{
${ }^{3}$ In our view, Narayan and Singh (2007) should have used the standard neoclassical production function augmented with electricity consumption. This could have provided useful insights on whether electricity consumption has permanent level or growth effects on output. However, they have given a good detail of the energy sector in Fiji.
} 
The uniqueness of this paper is, first, that it is a case study of the demand for energy in a small island state (Fiji's GDP per head of population at 1995 constant prices for 2005 was only US\$1799), second, that it applies modern time series techniques to examine the demand for energy in both the long run and the short run, and third, that it investigates the causality relationship between energy consumption, GDP and energy prices.

The time series properties of energy consumption, real GDP and real energy prices are examined with the Augmented Dicky-Fuller (ADF) and Elliot-RothenbergStock (ERS) tests. ${ }^{4}$ The results of the ADF and ERS unit root tests are presented in Table A in the Appendix. The null hypothesis of non-stationarity of energy consumption, real GDP and real energy prices is tested against the alternative hypothesis of stationarity. The ADF results indicate that the unit root null for the level variables cannot be rejected at $5 \%$ level. Alternatively, the null that their first differences have unit roots is undoubtedly rejected. Similarly, the computed ERS test statistics are more than the 5\% critical values, implying that all the levels of the variables are non-stationary. However, the test statistics are lower than critical values for the first difference of these variables and reject the unit root null at 5\% level. Therefore, the level variables are non-stationary and their first differences are stationary. We used Microfit 4.1 for estimating the equations. The sample period is 1970-2005. The definitions of variables and sources of data are presented in the Appendix.

\subsection{Cointegration and Granger Causality}

Regarding the existence of cointegrating relationship between energy consumption, income and energy prices, we use the General to Specific (GETS) and JML techniques. First, we applied the GETS approach where the general dynamic specification will have more lagged values of $\Delta \ln E, \Delta \ln Y$ and $\Delta \ln P$. The general dynamic equation can be specified as:

$$
\begin{aligned}
\Delta \ln E_{t} & =\beta_{0}+\beta_{1} \ln E_{t-1}+\beta_{2} \ln Y_{t-1}+\beta_{3} \ln P_{t-1} \\
& +\sum_{i=1}^{n} \lambda_{i} \Delta \ln E_{t-i}+\sum_{i=0}^{m} \gamma_{i} \Delta \ln Y_{t-i}+\sum_{i=0}^{j} T_{i} \Delta \ln P_{t-i}+\varepsilon_{t}
\end{aligned}
$$

Specifically, the demand for energy is estimated with a lag length of four periods. These were later reduced to parsimonious versions as reported in Table 3 . In Table 3 , Equation $\mathrm{G}(1)$ is the initial parsimonious version without any parameter restrictions. ${ }^{5}$ In Equation G(1), we tested for unit income elasticity with the Wald test and it could not reject the null that it is unity at the $5 \%$ level. The Wald test computed $X^{2}{ }_{(1)}$ test statistic

\footnotetext{
${ }^{4}$ It is well known that the ADF unit root test have low power against the unit root null hypothesis, therefore we also used a stronger test ie., ERS.

${ }^{5}$ The GETS equations are G(1) and G(2). G(1) could be regarded as an unrestricted ECM. The parameter restrictions are useful to increase the degrees of freedom and improve the summary statistics. Thus G(2) is the restricted equation with these benefits.
} 
with p-value in parenthesis is $0.526(0.468)$ is insignificant. The Equation $\mathrm{G}(2)$ is our preferred equation with this restriction.

\{Table 3 about here

It is worth noting that the implied unit income elasticity is significant with expected sign. The energy price elasticity is around -0.3 and highly significant with expected sign. The speed of adjustment $(\lambda)$ implies that departures from equilibrium in the previous period are reduced by about 45 percent in the subsequent period. The $X^{2}$ summary statistics indicate that there is insignificant serial correlation $\left(X^{2}{ }_{s c 1}\right)$, functional form misspecification $\left(X_{f f}^{2}\right)$, non-normality $\left(X_{n}^{2}\right)$ and heteroscedasticity $\left(X_{h s}^{2}\right)$ in the residuals.

In order to check whether the results are robust, we also applied the JML technique. ${ }^{6}$ The variables $\ln E, \ln Y$ and $\ln P$ are subjected to a VAR(4) framework. The Akaike Information Criteria (AIC) and Schwartz Bayesian Criteria (SBC) criteria reached a maximum of 140.364 and 133.768, respectively, implying that lag length is one period. We selected the restricted intercepts and no trends option because only this option gave us meaningful results. ${ }^{7}$ The maximal eigenvalue and trace test statistics for the null that there is no cointegration are 84.028 and 118.938 , respectively. The $95 \%$ critical values, respectively, are 22.040 and 34.870 . For the null that there is one cointegrating vector, the corresponding test statistics, with the $95 \%$ critical values in the parentheses are 3.903 (9.160) and 14.910 (20.180), respectively. Therefore, the null hypothesis that there is no cointegration is rejected but the null that there exists at least one cointegrating vector is not rejected. The implied cointegrating vector normalized on $\ln E$ is given by Equation (4).

$$
\begin{array}{r}
\ln \tilde{E}_{t}=-0.979+1.049 \ln Y_{t}-0.250 \ln P_{t} \\
(19.59)^{*}(6.68)^{*} \quad(3.89)^{*}
\end{array}
$$

The implied income elasticity is around unity and the energy price elasticity is around -0.25 . Both of these crucial elasticities are significant and plausible. The unit income elasticity imply that economic growth is likely to be accompanied by proportional increases in energy demand. On the relationship between real energy price and energy

\footnotetext{
${ }^{6}$ The General to Specific (GETS) technique, developed by the London School of Economics Professor Hendry, considers a broad dynamic lag structure between the dependent and independent variables. The cointegrating equations consist of the lagged levels and first differences of the variables. According to Hendry, the general unrestricted model can be reduced by utilizing the standard variable deletion tests and thus a parsimonious dynamic adjustment model is attained. For merits of GETS technique, see Rao et al. (2010). In contrast, Johansen's (1988) maximum likelihood (JML) method is a systems based approach where in the first stage the order of the VAR is determined. In the second stage the Eigenvalue and Trace tests are used to test for the existence of cointegrating vector(s). Identification and endogeneity tests are also mandatory in this method. A good exposition of the JML technique can be found in Holtedahl and Joutz (2004), Singh and Kumar (2009) and Kumar (2009).

${ }^{7}$ The results from other options such as no intercept or trend, unrestricted intercept no trend, unrestricted intercept restricted trend and unrestricted intercept unrestricted trend gave implausible income elasticity.
} 
consumption, the results imply that a 1 percent increase in energy price leads to about 0.25 percent fall in energy consumption.

We attained the JML short run dynamic demand for energy equation by adopting the lag search procedure used in the GETS approach. We started with a very general specification as follows:

$$
\begin{aligned}
\Delta \ln E_{t} & =\beta_{0}+\beta_{1} E C T_{t-1} \\
& +\sum_{i=1}^{n} \lambda_{i} \Delta \ln E_{t-i}+\sum_{i=0}^{m} \gamma_{i} \Delta \ln Y_{t-i}+\sum_{i=0}^{j} T_{i} \Delta \ln P_{t-i}+\varepsilon_{t}
\end{aligned}
$$

where $\Delta \ln E_{t}$ is regressed on its lagged values, the current and lagged values of $\Delta \ln Y_{t}$ and $\Delta \ln P_{t}$ and the lagged error term of the corresponding cointegrating equation. We have used lags up to 4 periods on energy consumption, real GDP and real energy prices. $E C T_{t-1}$ is the lagged residual from the cointegrating equation. By using the standard variable deletion tests, we arrived at the parsimonious equation $(\mathrm{J} 1)$ as reported in Table 3. It is worth noting that the coefficient of the lagged error term $\left(E C T_{t-1}\right)$ serves as negative feedback mechanism and implies that departures from equilibrium in the previous period are reduced by about $46 \%$ in the subsequent period. The $X^{2}$ statistics are also reasonable.

\{Table 4 about here $\}$

Since there is a cointegrating relationship between energy consumption, GDP and energy prices, we proceed further to determine the causality relationship between these variables. The JML based Granger causality test is applied for both short run and long run situations. Table 4 presents these results. The $F$ test of the lagged exogenous variables indicates short run causal effects. The long run causal effect is determined by the significance ( $t$-ratio) of the one period lagged error correction term. For more details on Granger causality, see Lise and Montfort (2007). In the short run effects, both the energy consumption and energy prices are insignificant at 5\% level in the GDP equation. This implies that both energy consumption and price do not Granger cause GDP in the short run. Similarly, in the energy price equation the energy consumption and GDP are insignificant at 5\% level. However, GDP is significant at 5\% level in the energy consumption equation. This implies that GDP does Granger cause energy consumption. The long run results suggest that the coefficient of the lagged error term $\left(E C T_{t-1}\right)$ is significant at $5 \%$ level with correct negative sign in the energy consumption equation. This implies that in the long run both GDP and energy prices Granger cause energy consumption. In other words, the causality runs interactively through the error correction term from GDP and energy prices to energy consumption.

\section{Conclusions and Policy Implications}

This paper has used GETS and JML time series techniques to examine the relationships 
between energy consumption, real GDP and real energy prices for Fiji over the period 1970-2005. Specifically, the study applies the ADF and ERS unit root tests to ascertain the time series properties of the variables. The results from the unit root tests indicate that the energy consumption, real GDP and real energy prices are first difference stationary. The study applied the GETS and JML techniques to determine the long run relationships between these variables. The results of both the methods indicate the series are cointegrated.

The unit income elasticity of total energy demand implies that economic growth is likely to be accompanied by proportional increases in energy demand. The energy price elasticity is around -0.3 , implying that a 1 percent increase in energy price leads to about 0.3 percent decrease in energy consumption. There is some degree of responsiveness of energy demand to price changes and these suggest that raising energy prices are likely to achieve government goals for energy conservation or environmental improvement.

The JML framework enables us to check for Granger causality both in the short and the long run. We find that in the short run, there is causality running from GDP to energy consumption. This implies that Fiji is not dependent on energy consumption for growth and development in the short run. However, in the long run both GDP and energy prices Granger cause energy consumption. Thus, in both cases the Granger causality test provides strong justification for energy conservation policies in Fiji.

Needless to say there are some limitations in this paper. First, we did not test for structural breaks in the cointegrating relationship. There may be intercept, trend and/or slope shifts in the data due to external shocks, however we have attempted to use a dummy variable to capture these effects but the estimates were insignificant. Second, we did not perform the cointegration analysis based on disaggregate data which may provide some useful policy insights related to individual energy use. Third, we ignored to consider non-linearities in the data. Therefore future research could focus on analysing energy demand for Fiji or other developing nations using threshold cointegration methods. 


\section{References}

Al-Rabbaie, A. and Hunt, L.C. (2004) 'Panel unit roots and cointegration: evidence for OECD energy demand,' IAEE European Conference paper (Zurich), 1-24.

Al-Azzam, A. and Hawdon, D. (1999) 'Estimating the demand for energy in Jordan: a Stock-Watson dynamic OLS (DOLS) approach,' Surrey Energy Economics Centre, Department of Economics, University of Surrey.

Al-faris, A.F. (1992) 'Income and price elasticity of gasoline demand in the Organization of Arab Petroleum Exporting Countries,' Journal of Energy and Development, 17, 209-223.

Al-Iriani, M. (2006) 'Energy-GDP relationship revisited: An example from GCC countries using panel causality,' Energy Policy, 34, 3342-3350.

Aqeel, A. and Butt, M.S. (2001) 'The relationship between energy consumption and economic growth in Pakistan,' Asia-Pacific Development Journal, 8, 101-110.

Brenton, P. (1997) 'Estimates of the demand for energy using cross-country consumption data,' Applied Economics, 29, 851-859.

Cheng, B.S. and Lai, T.W. (1997) 'An investigation of co-integration and causality between energy consumption and economic activity in Taiwan,' Energy

Economics, 19, 435-444.

Chiou-Wei, S.Z., Chen, C-F. and Zhu, Z. (2008) 'Economic growth and energy consumption revisited- evidence from linear and nonlinear Granger causality,' Energy Economics, 30, 3063-3076.

Current Economic Statistics (various issues), Fiji Islands Bureau of Statistics, Suva.

De Vita, G., Endresen, K. and Hunt, L.C. (2006) 'An empirical analysis of energy demand in Namibia,' forthcoming in Energy Policy.

Diabi, A (1998) 'The demand for electric energy in Saudi Arabia: an empirical investigation,' OPEC Review, 24, 13-29.

Eltony, M.N. (1996) 'An econometric study of the demand for gasoline in the Gulf Cooperation Council Countries,' The Journal of Energy and Development, 19, 265-273.

Eltony, M.N. and Hoque, A. (1996) 'A cointegrating relationship in the demand for energy: The case of electricity in Kuwait,' Journal of Energy and Development, 21, 293-301. 
Fisher-Vanden, K., Jefferson, G.H., Liu, H., and Tao, Q. (2004) 'What is driving China's decline in energy intensity,' Resource and Energy Economics, 26, 77-97.

Galli, R. (1998) 'The relationship between energy intensity and income levels: forecasting long term energy demand in Asian emerging countries,' The Energy Journal, 19, 85-105.

Holtedahl, P. and Joutz, F.L. (2004) 'Residential electricity demand in Taiwan,' Energy Economics, 26, 201-224.

Hunt, L.C., Judge, G. and Ninomiya, Y. (2003) 'Modelling underlying energy demand trends,' Chapter 9 in L.C. Hunt (Ed.) Energy in a competitive market: Essays in Honour of Colin Robinson, Edward Elgar, May, 140-174.

International Financial Statistics, December, 2005. IMF CD-ROM (Washington DC: International Monetary Fund).

Johansen, S. (1988) 'Statistical analysis of cointegrating vectors,' Journal of Economics Dynamics and Control, 12, 231-254.

Jumbe, C.B.L. (2004) 'Cointegration and causality between electricity consumption and GDP: empirical evidence from Malawi,' Energy Economics, 26, 61-68.

Key World Energy Statistics (2001 Edition), International Energy Agency, Paris.

Kumar, S. (2009) 'A re-examination of private consumption in Fiji,'Pacific Economic Bulletin, 24, 70-81.

Lee, C.C. (2005) 'Energy consumption and GDP in developing countries: A cointegrated panel analysis,' Energy Economics, 27, 415-427.

Lise, W. and Montfort, K.V. (2007) 'Energy consumption and GDP in Turkey: Is there a co-integration relationship?’ Energy Economics, 29, 1166-1178.

Mahadevan, R. and Asafu-Adjaye, J. (2007) 'Energy consumption, economic growth and prices: A reassessment using panel VECM for developed and developing countries,' Energy Policy, 35, 2481-2490.

Masih, R. and Masih, A.M.M (1996a) 'Stock-Watson dynamic OLS (DOLS) and errorcorrection modelling approaches to estimating long- and short-run elasticities in a demand function: New evidence and methodological implications from an application to the demand for coal in Mainland China,' Energy Economics, 20, 315-334. 
Masih, A.M.M and Masih, R. (1996b) 'Energy consumption, real income and temporal Causality: results from multi country study based on cointegration and error correction modeling technique, Energy Economics, 18, 165-183.

Mohammad, Y.H. and Eltony, M.N. (1996) 'The demand for natural gas in the Gulf Cooperation Council (GCC) states,' Middle East Business and Economic Review, $8,41-48$.

Narayan, P.K. and Singh, B. (2007) 'The electricity consumption and GDP nexus for the Fiji Islands, Energy Economics, 29, 1141-1150.

Overseas Trade Reports (various issues), Fiji Islands Bureau of Statistics, Suva.

Pedroni, P. (2001) 'Purchasing power parity tests in cointegrated panel,' The Review of Economics and Statistics, 83, 727-731.

Pesaran, M.H., Smith, R. and Akiyama, T. (1998) 'Energy demand in Asian economies,' Oxford: Oxford University Press.

Rao, B.B. and Rao, G. (2009a) 'Cointegration and the demand for gasoline,' Energy Policy, 37, 3978-3983.

(2009b) 'Structural breaks and energy efficiency in Fiji,' Energy Policy, 37, 3959-3966.

Saed, A.A.J. (2004) 'Estimation of total energy consumption in Jordan 1980-1999: Evidence from cointegration and stock,' Journal of Economic and Administrative Sciences, 20, 71-82.

Singh, R. and Kumar, S. (2009) 'Application of the alternative techniques to estimate demand for money in developing countries,' forthcoming in the Journal of Developing Areas.

Sinton, J. and Fridley, D. (2000) 'What goes up: recent trends in China's energy Consumption,' Energy Policy, 28, 671-87.

Wolde-Rufael, Y. (2004) 'Disaggregated industrial energy consumption and GDP: the case of Shanghai, 1952-1999,' Energy Economics, 26, 69-75.

Yoo, S. H. (2006) 'The causal relationship between electricity consumption and economic growth in the ASEAN countries,' Energy Policy, 34, 3573-3582.

Zamani, M. (2006) 'Energy consumption and economic activities in Iran,' Energy Economics, 29, 1135-1140. 


\section{Data Appendix A.) Definition of Variables}

$E$ is the total energy consumption in mega joules for Fiji. $E$ is the sum of electricity, unleaded gasoline, automotive diesel, industrial diesel, kerosene and gas. Data Source: Overseas Trade Reports, Fiji Islands Bureau of Statistics, Suva, various issues.

$Y$ is the real GDP at factor cost in 1995 prices. Data Source: International Financial Statistics (2005).

$P$ is the real price index of energy, computed as the weighted average of Fiji's real price indexes from the industrial sector, commercial sector and domestic sector. Data Source: Overseas Trade Reports, Fiji Islands Bureau of Statistics, Suva, various issues.

\section{B.) Table A: ADF and ERS Unit Root Tests}

\begin{tabular}{|l|l|l|c|}
\hline Variable & LAG & ADF & ERS \\
\hline $\ln E$ & {$[1,1]$} & -1.650 & 9.562 \\
& & $(-3.562)$ & $(3.66)$ \\
$\ln E$ & {$[0,2]$} & -9.983 & 4.809 \\
$\ln Y$ & & $(-3.567)$ & $(7.23)$ \\
& & -2.724 & 45.742 \\
$\Delta \ln Y$ & {$[1,2]$} & $(-3.562)$ & $(2.85)$ \\
& & -8.634 & 4.026 \\
$\ln P$ & {$[0,0]$} & $(-3.567)$ & $(12.87)$ \\
& & -1.451 & 26.817 \\
$\Delta \ln P$ & {$[1,2]$} & $(-3.562)$ & $(6.68)$ \\
& & -4.085 & 5.703 \\
& {$[0,1]$} & $(-3.567)$ & $(13.47)$ \\
\hline
\end{tabular}

Notes: LAG is the lag length of the first differences of the variables. For example $[1,1]$ means that one lagged first difference is found to be adequate in the two test statistics, respectively. For both ADF and ERS, the 5\% critical values are given below the test statistics in parentheses. A time trend is included because it is significant in levels and first differences of the variables. ADF and ERS tests were conducted in Microfit 4.1 and E-views, respectively. The lag lengths $(L A G)$ are chosen based on the following criteria:

1. Set an upper bound $L A G_{\max }$ for $L A G$.

2. Estimate the ADF test regression with $L A G=L A G_{\max }$.

3. If the absolute value of the t-statistic for testing the significance of the last lagged difference is greater than 1.6 then set $L A G=L A G_{\max }$ and perform the unit root test. Otherwise, reduce the lag length by one and repeat the process. 
C.) Table 1. Growth of Energy Consumption, Real GDP, Real Energy Price and Energy Output Ratios: 1970-2005

\begin{tabular}{|l|l|l|l|l|}
\hline Year & $\Delta \ln E$ & $\Delta \ln \boldsymbol{\Delta}$ & $\Delta \ln P$ & $\begin{array}{l}\Delta \ln \\
(\boldsymbol{E} / \boldsymbol{Y})\end{array}$ \\
\hline $1970-1980$ & 3.991 & 4.651 & 7.972 & 0.858 \\
$1981-1990$ & 1.014 & 2.243 & 3.924 & 0.452 \\
$1991-2000$ & 1.022 & 2.257 & 5.284 & 0.453 \\
$2001-2005$ & 3.041 & 2.406 & 6.632 & 1.264 \\
$1970-2005$ & 2.127 & 2.958 & 5.990 & 0.719 \\
\hline
\end{tabular}


D.) Table 2. Studies of Demand for Energy and their Findings

\begin{tabular}{|c|c|c|c|c|c|c|}
\hline Authors & Period & Country & $\begin{array}{l}\text { Cointegration } \\
\text { Method } \\
\end{array}$ & $\mathrm{e}_{\mathrm{y}}$ & $\mathrm{e}_{\mathrm{ep}}$ & Other Findings \\
\hline $\begin{array}{l}\text { Al-Azzam } \\
\text { and } \\
\text { Hawdon } \\
(1999)\end{array}$ & $\begin{array}{l}1968- \\
1997\end{array}$ & Jordan & $\begin{array}{l}\text { JML } \\
\text { DOLS }\end{array}$ & $\begin{array}{l}1 \\
1\end{array}$ & $\begin{array}{l}-0.22 \\
-0.08\end{array}$ & - \\
\hline $\begin{array}{l}\text { Saed } \\
(2004)\end{array}$ & $\begin{array}{l}1980- \\
1999\end{array}$ & Jordan & DOLS & 1.15 & -1.14 & - \\
\hline $\begin{array}{l}\text { Lise and } \\
\text { Montfort } \\
(2007) \\
\end{array}$ & $\begin{array}{l}1970- \\
2003\end{array}$ & Turkey & $\begin{array}{l}\text { Granger } \\
\text { causality tests }\end{array}$ & - & - & $\begin{array}{l}\text { Causality from } \\
\text { GDP to energy } \\
\text { consumption }\end{array}$ \\
\hline $\begin{array}{l}\text { De Vita et. } \\
\text { al (2006) }\end{array}$ & $\begin{array}{l}\text { 1980(Q1)- } \\
\text { 2002(Q4) }\end{array}$ & Namibia & ARDL & 1.3 & -0.3 & - \\
\hline $\begin{array}{l}\text { Zamani } \\
(2007)\end{array}$ & $\begin{array}{l}1967- \\
2003\end{array}$ & Iran & JML & - & - & $\begin{array}{l}\text { Causality from } \\
\text { GDP to energy } \\
\text { consumption. }\end{array}$ \\
\hline $\begin{array}{l}\text { Wolde- } \\
\text { Rufael } \\
(2004)\end{array}$ & $\begin{array}{l}1952- \\
1999\end{array}$ & Shanghai & $\begin{array}{l}\text { Granger } \\
\text { causality tests }\end{array}$ & - & - & $\begin{array}{l}\text { Causality from } \\
\text { energy } \\
\text { consumption to } \\
\text { GDP }\end{array}$ \\
\hline $\begin{array}{l}\text { Al-Rabbaie } \\
\text { and Hunt } \\
(2004)\end{array}$ & $\begin{array}{l}1960- \\
2000\end{array}$ & $\begin{array}{l}17 \\
\text { OECD }\end{array}$ & $\begin{array}{l}\text { Pedroni } \\
(2001)\end{array}$ & 0.96 & -0.09 & - \\
\hline $\begin{array}{l}\text { Rao and } \\
\text { Rao } \\
(2009 a)\end{array}$ & $\begin{array}{l}1970- \\
2005\end{array}$ & Fiji & $\begin{array}{l}5 \text { time series } \\
\text { estimators }\end{array}$ & 0.45 & -0.20 & $\begin{array}{l}\text { Gasoline demand } \\
\text { is price and } \\
\text { income inelastic. }\end{array}$ \\
\hline $\begin{array}{l}\text { Narayan } \\
\text { and Singh } \\
(2007)\end{array}$ & $\begin{array}{l}1971- \\
2002\end{array}$ & Fiji & ARDL & - & - & $\begin{array}{l}\text { Causality from } \\
\text { electricity } \\
\text { consumption and } \\
\text { labour force to } \\
\text { GDP. }\end{array}$ \\
\hline $\begin{array}{l}\text { Holtedahl } \\
\text { and Joutz } \\
(2004) \\
\end{array}$ & $\begin{array}{l}1959- \\
1995\end{array}$ & Taiwan & JML & 1.04 & -0.16 & - \\
\hline $\begin{array}{l}\text { Jumbe } \\
\text { (2004) }\end{array}$ & $\begin{array}{l}1970- \\
1999\end{array}$ & Malawi & JML & - & - & $\begin{array}{l}\text { Causality from } \\
\text { GDP to } \\
\text { electricity } \\
\text { consumption. }\end{array}$ \\
\hline
\end{tabular}

$\mathrm{e}_{\mathrm{y}}$ and $\mathrm{e}_{\mathrm{ep}}$, respectively, denotes income elasticity and energy price elasticity. A (-) indicates that the information was not provided by the author. JML, DOLS and ARDL means Johansen Maximum Likelihood, Dynamic Ordinary Least Squares and Auto-regressive Distributed Lag, respectively. 
E.) Table 3: GETS and JML Estimates

\begin{tabular}{|c|c|c|c|}
\hline & G(1) & $\mathbf{G}(2)$ & $\mathbf{J}(\mathbf{1})$ \\
\hline Intercept & $\begin{array}{c}-1.046 \\
(-3.44)^{*}\end{array}$ & $\begin{array}{c}-0.942 \\
(-4.52) *\end{array}$ & $\begin{array}{c}-0.094 \\
(-2.56) *\end{array}$ \\
\hline$\lambda$ & $\begin{array}{c}-0.322 \\
(-6.78)^{*}\end{array}$ & $\begin{array}{c}-0.449 \\
(-6.95)^{*}\end{array}$ & \\
\hline $\ln Y_{t-1}$ & $\begin{array}{c}1.066 \\
(8.85)^{*}\end{array}$ & $\begin{array}{c}1.000 \\
(\mathrm{c})\end{array}$ & \\
\hline $\ln P_{t-1}$ & $\begin{array}{c}-0.314 \\
(-4.50) *\end{array}$ & $\begin{array}{c}-0.301 \\
(-5.63) *\end{array}$ & \\
\hline$E C T_{t-1}$ & & & $\begin{array}{c}-0.457 \\
(-5.23) *\end{array}$ \\
\hline$\Delta \ln Y_{t}$ & $\begin{array}{c}0.557 \\
(2.17)^{*}\end{array}$ & $\begin{array}{c}1.734 \\
(2.64) *\end{array}$ & $\begin{array}{c}2.350 \\
(3.08)^{*}\end{array}$ \\
\hline$\Delta \ln Y_{t-2}$ & $\begin{array}{c}-1.251 \\
(-1.69)^{* *}\end{array}$ & $\begin{array}{c}-1.802 \\
(-2.15)^{*}\end{array}$ & \\
\hline$\Delta \ln Y_{t-3}$ & & & $\begin{array}{c}-1.742 \\
(-2.43)^{*} \\
\end{array}$ \\
\hline$\Delta \ln E_{t-2}$ & $\begin{array}{c}-0.477 \\
(-1.64)^{* *}\end{array}$ & $\begin{array}{c}-0.498 \\
(-2.01)^{*}\end{array}$ & \\
\hline$\Delta \ln P_{t}$ & $\begin{array}{l}-0.190 \\
(-1.59) \\
\end{array}$ & $\begin{array}{c}-0.062 \\
(-2.27)^{*}\end{array}$ & $\begin{array}{c}3.880 \\
(2.71)^{*}\end{array}$ \\
\hline$\Delta \ln P_{t-1}$ & & & $\begin{array}{c}2.180 \\
(2.56)^{*}\end{array}$ \\
\hline$\Delta \ln P_{t-3}$ & $\begin{array}{c}1.122 \\
(2.38)^{*}\end{array}$ & $\begin{array}{c}1.783 \\
(4.75) *\end{array}$ & $\begin{array}{c}3.837 \\
(3.21)^{*}\end{array}$ \\
\hline Adjusted $R^{2}$ & 0.722 & 0.765 & 0.687 \\
\hline SEE & 0.056 & 0.048 & 0.076 \\
\hline$X_{s c l}^{2}$ & $\begin{array}{l}0.021 \\
(0.87)\end{array}$ & $\begin{array}{l}0.031 \\
(0.86) \\
\end{array}$ & $\begin{array}{l}0.689 \\
(0.41) \\
\end{array}$ \\
\hline$X_{f f}^{2}$ & $\begin{array}{l}0.685 \\
(0.71) \\
\end{array}$ & $\begin{array}{l}0.725 \\
(0.70) \\
\end{array}$ & $\begin{array}{l}1.424 \\
(0.23) \\
\end{array}$ \\
\hline$X_{n}^{2}$ & $\begin{array}{l}0.025 \\
(0.87) \\
\end{array}$ & $\begin{array}{l}0.019 \\
(0.89) \\
\end{array}$ & $\begin{array}{l}0.111 \\
(0.95) \\
\end{array}$ \\
\hline$X_{h s}^{2}$ & $\begin{array}{l}0.463 \\
(0.50) \\
\end{array}$ & $\begin{array}{l}1.497 \\
(0.22) \\
\end{array}$ & $\begin{array}{l}1.497 \\
(0.22) \\
\end{array}$ \\
\hline
\end{tabular}

The dependent variable is $\Delta \ln E_{t}$. The $t$-ratios for the variables and the $p$-values for the chi-square $\left(X^{2}\right)$ tests are in parentheses. * and ** indicate significance at the 5 percent and 10 percent levels, respectively. $\lambda$ measures speed of adjustment to equilibrium. (c) is the restricted variable. The GETS based equations are G(1) and $\mathrm{G}(2)$ and JML based equation is $\mathrm{J}(1)$. The estimation period is 1970-2005. 
F.) Table 4. Results of Granger Causality Test

\begin{tabular}{|l|l|l|l|l|}
\hline $\begin{array}{l}\text { Dependent } \\
\text { Variable }\end{array}$ & $\Delta \ln Y_{t}$ & $\Delta \ln E_{t}$ & $\Delta \ln P_{t}$ & $E C T_{t-1}$ \\
\hline$\Delta \ln Y_{t}$ & - & 0.0145 & -1.272 & - \\
& & $(0.82)$ & $(-1.23)$ & \\
\hline$\Delta \ln E_{t}$ & 0.332 & - & -0.278 & -0.457 \\
& $(2.53)^{*}$ & & $(-0.73)$ & $(-5.23)^{*}$ \\
\hline$\Delta \ln P_{t}$ & 1.827 & 0.374 & - & - \\
& $(0.46)$ & $(1.53)$ & & \\
\hline
\end{tabular}

The $t$-ratios are given in the parentheses. Significance at 5 percent level is denoted by *. 